\title{
KRYTERIA, JAKIE POWINNY SPEŁNIAĆ WSPÓŁCZESNE PRACE PROJEKTOWE PRZEKSZTAŁCAJĄCE FORMĘ I PROGRAM UŻYTKOWY ZABYTKOWEJ ARCHITEKTURY SAKRALNEJ W ŚWIETLE WYBRANYCH PRZYKŁADÓW Z EUROPY
}

\section{SZUMIŃSKI Konrad ${ }^{1}$}

${ }^{1}$ Konrad Szumiński, Wydział Architektury Politechniki Warszawskiej https://orcid.org/0000-0002-0466-2250

ABSTRAKT: Artykuł podejmuje wciąż aktualny problem przekształceń formy zabytkowej architektury sakralnej w procesie adaptacji do współczesnych funkcji użytkowych. Zjawisko sekularyzacji warunkuje konwersję funkcjonalną świątyń, a zatem wymaga od architektów odpowiedniego podejścia do projektowania w historycznym kontekście z poszanowaniem pierwiastka sacrum.

Celem przeprowadzonych badań było sformułowanie zasad, jakie powinny obowiązywać podczas interwencji projektowych w zabytkowych obiektach sakralnych.

Badania zostały oparte na studium przypadku wybranych przykładów z Europy, które ilustrują różny stopień ingerencji projektowych $\mathrm{w}$ historyczną substancję. Opisywane realizacje poddano ocenie konserwatorskiej na podstawie kryteriów dotyczących m.in. stopnia zachowania wartości zabytkowych oraz ze względu na charakter relacji między zabytkiem a współczesną formą architektury.

W wyniku analiz wyodrębniono wnioski końcowe odnoszące się do preferowanych cech funkcjonalnych, przestrzennych, konstrukcyjno-materiałowych współczesnych uzupełnień architektonicznych w zabytkowych miejscach kultu religijnego.

SŁOWA KLUCZOWE: architektura sakralna, sekularyzacja, sacrum, zabytek, adaptacja 


\section{Konrad Szumiński}

\section{Wprowadzenie}

Współczesny sposób użytkowania zabytków architektury i urbanistyki pociąga za sobą szereg ingerencji projektowych w ich formę, strukturę czy układ funkcjonalno-przestrzenny. Grupą obiektów zabytkowych, która staje się szczególnie narażona na szkodliwe skutki przekształceń w procesie ich adaptacji, jest architektura sakralna. Zjawisko laicyzacji życia społecznego w Europie, a w konsekwencji liczne konwersje funkcjonalne świątyń nasuwają potrzebę ustalenia granic dopuszczalnych interwencji w ich zabytkową formę. Jak pisze profesor Leon Dyczewski: Szczególnie symboliczna architektura i przestrzenia w mieście sa świątynie, kaplice, cmentarze, przyuliczne kaplice i krzyże. Wyróżnia je spośród innych budowli i przestrzeni symbolicznych to, że należa do sacrum, sa wyłączone $z$ jakichkolwiek form użyteczności, daja wiele do myślenia tym, którzy na nie patrza lub do nich wchodzą ${ }^{1}$. Najczęściej występującym rodzajem interwencji projektowej w zabytkowej tkance jest adaptacja obiektu sakralnego do współczesnych funkcji. $\mathrm{W}$ ostatnich latach powstało wiele cennych publikacji poruszających problematykę zmiany sposobu użytkowania i adaptacji architektury sakralnej². Ważnym głosem $\mathrm{w}$ dyskusji na temat sposobów użytkowania opuszczonych obiektów sakralnych jest publikacja autorstwa profesora Andrzeja Białkiewicza, prezentująca skalę opisywanej powyżej problematyki na licznych przykładach z Polski i Europy Zachodniej. ${ }^{3}$. W literaturze przedmiotu brak jednak próby wyodrębnienia konkretnych zasad/preferowanych działań projektowych w zabytkowej architekturze sakralnej

\section{Kryteria oceny przykładów}

Problem wpływu współczesnych form architektonicznych na percepcję obiektów zabytkowych poruszał m.in. profesor Andrzej Tomaszewski: (...) Architekt działajacy w zabytkowym otoczeniu ma trzy drogi do wyboru: konfrontacje form nowoczesnych $z$ historycznymi,

\footnotetext{
1 Dyczewski L., Wyganiane sacrum powraca, [w:] Miasto i sacrum, Kraków: Zakład Wydawniczy NOMOS, 2011, ss. 257-260. Lektura książki pobudza czytelnika do refleksji na temat roli architektury sakralnej we współczesnych miastach. Autorzy kolejnych rozdziałów opracowania zwracają uwagę na różne sposoby odczytywania pierwiastka sacrum oraz na jego niejednorodne przejawy.

2 Wśród nich do najważniejszych należy m.in.: Doroz-Turek M., Wartość sacrum w wybranych adaptacjach zdesakralizowanych kościołów i założeń klasztornych, [w:] Ochrona wartości w procesie adaptacji obiektów zabytkowych, Warszawa: PKN ICOMOS, 2015, ss. 85-103. Autorka opracowania zwraca szczególną uwagę na wartości niematerialne, których zachowanie staje się niezbędne w kontekście odpowiedniego wyeksponowania zidentyfikowanych wartości zabytkowych sakralnego obiektu architektonicznego.

${ }^{3}$ Białkiewicz A., O zmianach użytkowania obiektów sakralnych, Kraków: Wydawnictwo Politechniki Krakowskiej, 2016. Autor opisuje przykłady zmian użytkowania świątyń w krajach Europy Zachodniej (Włochy, Belgia, Holandia, Francja, Wielka Brytania) oraz w Polsce (głównie na przykładzie zespołów klasztornych zakonu paulinów).

${ }^{4}$ Pogłębione badania nad rozwiązaniami architektonicznymi w adaptowanych zabytkowych kościołach odnajdziemy w obronionych w ostatnich latach rozprawach doktorskich m.in. w: Długosz D., Adaptacja zabytkowych kościołów katolickich do nowych funkcji na wybranych przyktadach w Polsce oraz w Europie Zachodniej (promotor: prof. zw. dr hab. inż. arch. Andrzej Kadłuczka, Politechnika Krakowska im. Tadeusza Kościuszki), 2019; Wojtuszek M., Architektoniczne aspekty adaptacji kościołów w Europie (promotor: dr hab. inż. arch. Jan Pallado, Politechnika Śląska), 2015.
} 
wprowadzenie form "neutralnych” lub „pastiszu”. Wszystkie sa trudne (... $)^{5}$. Wydaje się, że środowisko konserwatorskie wciąż poszukuje odpowiedzi na liczne pytania dotyczące granic dopuszczalnych ingerencji projektowych $\mathrm{w}$ historycznym kontekście. Doktor Małgorzata Włodarczyk w jednej z publikacji pisze: (...) Jaka jest zatem wspótczesna myśl architektoniczna dotyczaca działania wobec historycznego dziedzictwa albo raczej jaka powinna być? Odpowiedź wydaje się oczywista. Po prostu wspótczesna, ale nie niwecząca, dodająca wartości $i$ będąca tzw. dobra kontynuacją ${ }^{6}$. Jakie kryteria powinna zatem spełniać wspomniana wcześniej architektura współczesna rozumiana jako wartość dodana w środowisku kulturowym?

W dalszej części pracy przedstawiono problematykę konserwatorską kilku celowo wybranych, najnowszych przykładów przekształceń zabytkowych obiektów sakralnych z Europy Zachodniej, które najpełniej ilustrują różny stopień ingerencji w historyczną substancję. Zakres i stopień ingerencji został zaznaczony na kolejnych ilustracjach kolorem pomarańczowym. Realizacje zostały poddane ocenie na podstawie sformułowanych przez Autora kryteriów takich jak:

- Kryterium odróżnialności formy wspólczesnej od historycznej.

- Kryterium czytelności historycznej struktury.

- Kryterium czytelności historycznej funkcji.

- Kryterium spójności/integralności kompozycyjnej.

- Kryterium odwracalności przeksztatceń.

Niniejszy artykuł jest autorską próbą porównania różnorodnych ingerencji projektowych w zabytki z punktu widzenia architekta i konserwatora, który stara się zdefiniować zestaw preferowanych cech nowych uzupełnień (przede wszystkim kubaturowych) w historycznym kontekście. Kluczem doboru wyżej wymienionych kryteriów była chęć syntetycznego przedstawienia cech poszczególnych kreacji architektonicznych.

\section{Studium przypadku}

- wielofunkcyjne centrum z biblioteka i muzeum, Vught (Holandia), 2018

Pierwszą realizacją, która została poddana analizie, jest projekt adaptacji ceglanego kościoła w holenderskiej miejscowości Vught. Obiekt pochodzi z końca XIX wieku i w 2018 roku został zaadaptowany na wielofunkcyjne centrum z biblioteką, muzeum, restauracją oraz sklepami (Il. 1). Architekci zaprojektowali niską, parterową kubaturę z antresolą, która „wylewa” się na zewnątrz świątyni, organizując zadaszoną część gastronomiczną. Poza obrys rzutu kościoła celowo wypchnięto wszystkie komercyjne funkcje - restaurację, sklepy itd., natomiast przestrzeń

${ }_{5}$ Tomaszewski A., Ku nowej filozofii dziedzictwa, Kraków: Międzynarodowe Centrum Kultury, 2012, ss. 119-120.

${ }^{6}$ Włodarczyk M., Wspólczesna myśl architektoniczna w adaptacji obiektu zabytkowego, czyli charakterystyka optymalnej ingerencji dla potrzeb nowej funkcji, [w:] Adaptacja obiektów zabytkowych do współczesnych funkcji użytkowych, Warszawa: PKN ICOMOS, 2009, ss. 203-208. 
wewnątrz świątyni przeznaczono na ogólnodostępne funkcje kulturalne związane z biblioteką i muzeum, co należy uznać za rozwiązanie korzystne z punktu widzenia rangi adaptowanej przestrzeni sakralnej. Współczesne uzupełnienie ahistoryczne $\mathrm{w}$ formie niezależnej, ażurowej konstrukcji stalowej ze szklanym wypełnieniem spełnia kryterium jednoznacznej odróżnialności nowej formy od starej, jednakże częściowo zaburza czytelność układu funkcjonalno-przestrzennego w środku kościoła. Od strony zewnętrznej uzupełnienie słusznie operuje zupełnie innym, współczesnym językiem architektonicznym, ale kontrastująca, mocna $\mathrm{w}$ wyrazie, jasna płaszczyzna zadaszenia restauracji konkuruje wizualnie $\mathrm{z}$ formą zabytkowego kościoła i bardzo trudno jest doszukać się czytelnych rozwiązań i pomysłów na zapewnienie spójności kompozycyjnej. Pawilon nie tworzy z zabytkiem harmonijnej, integralnej, spójnej pod względem kompozycyjnym i kolorystycznym całości. Niewątpliwą zaletą prezentowanego rozwiązania przestrzennego jest możliwa (oczywiście do pewnego stopnia) odwracalność proponowanych przekształceń.

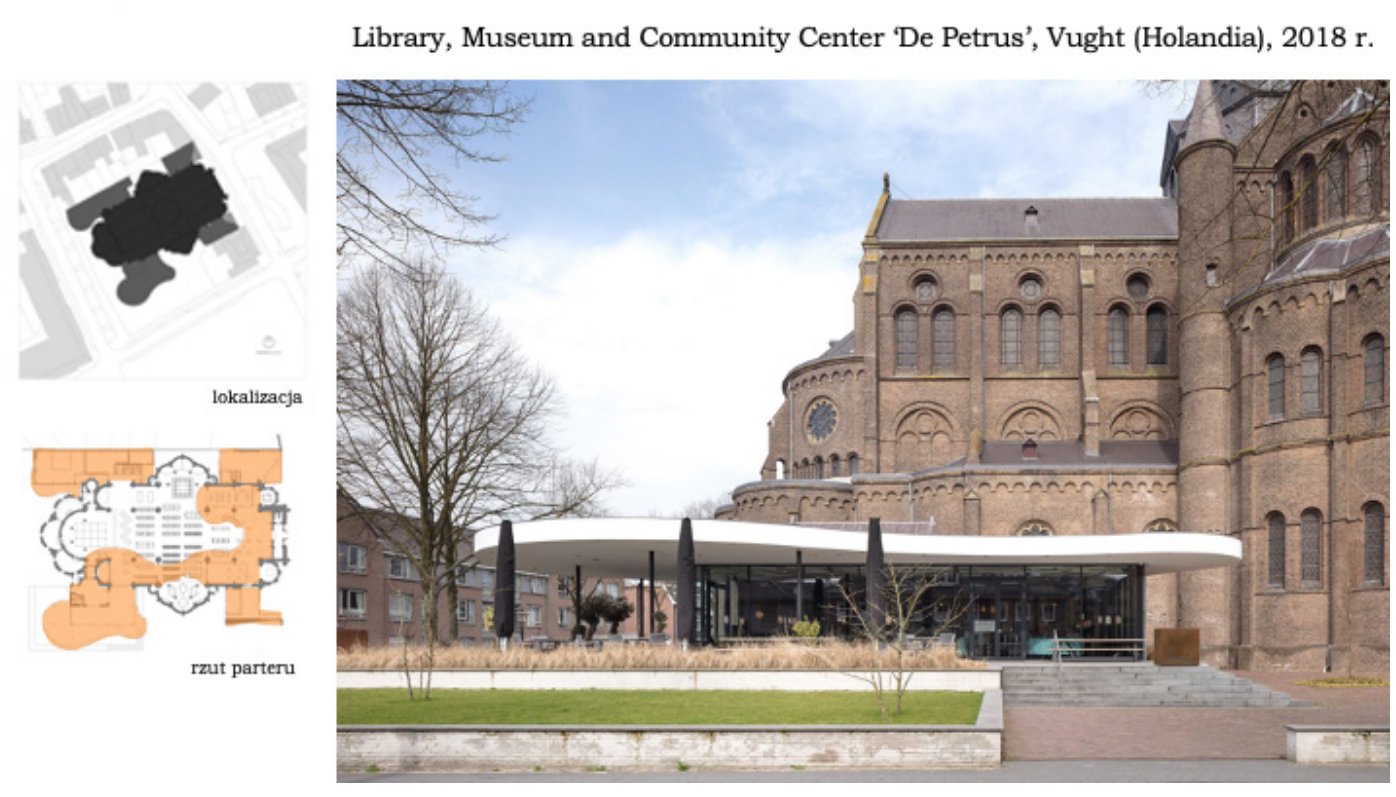

Il. 1. Library, Museum and Community Center 'De Petrus', Holandia (2018) - zestawienie kubatury historycznej ze współczesną, źródło: https://www.archdaily.com/892558/library-museum-and-community-center-de-petrusmolenaar-and-bol-and-vandillen-architects (dostęp: 20.09.2021).

- ośrodek zdrowia i odnowy biologicznej, Borne (Holandia), 2017

Drugimprzykłademingerencjiprojektowychwzabytkowejstrukturzejestadaptacjaneogotyckiego kościoła z początku XX wieku zlokalizowanego w niewielkiej wsi Borne. Zarówno diecezja, jak i lokalni lekarze zainicjowali konwersję świątyni na centrum opieki zdrowotnej i odnowy biologicznej. Celem było przywrócenie kościołowi społecznej, publicznej roli tak, aby pozostał on wartościowy dla mieszkańców wsi. W dawnej świątyni zaprojektowano współczesne uzupełnienie ahistoryczne $\mathrm{w}$ formie nieregularnej, trójkondygnacyjnej, niezależnej statycznie kubatury 
$\mathrm{z}$ antresolą, która tworzy coś w rodzaju wewnętrznego dziedzińca wewnątrz kościoła, służącego jako poczekalnia dla pacjentów (Il. 2). Uskokowe ukształtowanie formy nowego uzupełnienia pozwala na jednoznaczne odróżnienie nowych form architektonicznych od zabytkowych, jednak wprowadzaniepotrzebnychaosprzestrzenny,zaburzająctymsamymczytelnośćhistorycznejfunkcji i struktury zabytku. Zastosowano lekkie ściany z polistyrenu wzmocnione zbrojeniem z włókna stalowego, pokryte od strony zewnętrznej tynkiem natryskowym ${ }^{7}$. Taki typ konstrukcji posiada atut niezależnej statycznie struktury, którą można dowolnie modelować na etapie projektowania, a w przyszłości zdemontować, ale jednocześnie jej kształt sprawia wrażenie przypadkowego, nie tworzącego z zabytkowym kościołem spójnej i integralnej kompozycyjnie całości.

'De poort van Borne' Healthcare Center, Borne (Holandia), $2017 \mathrm{r}$.
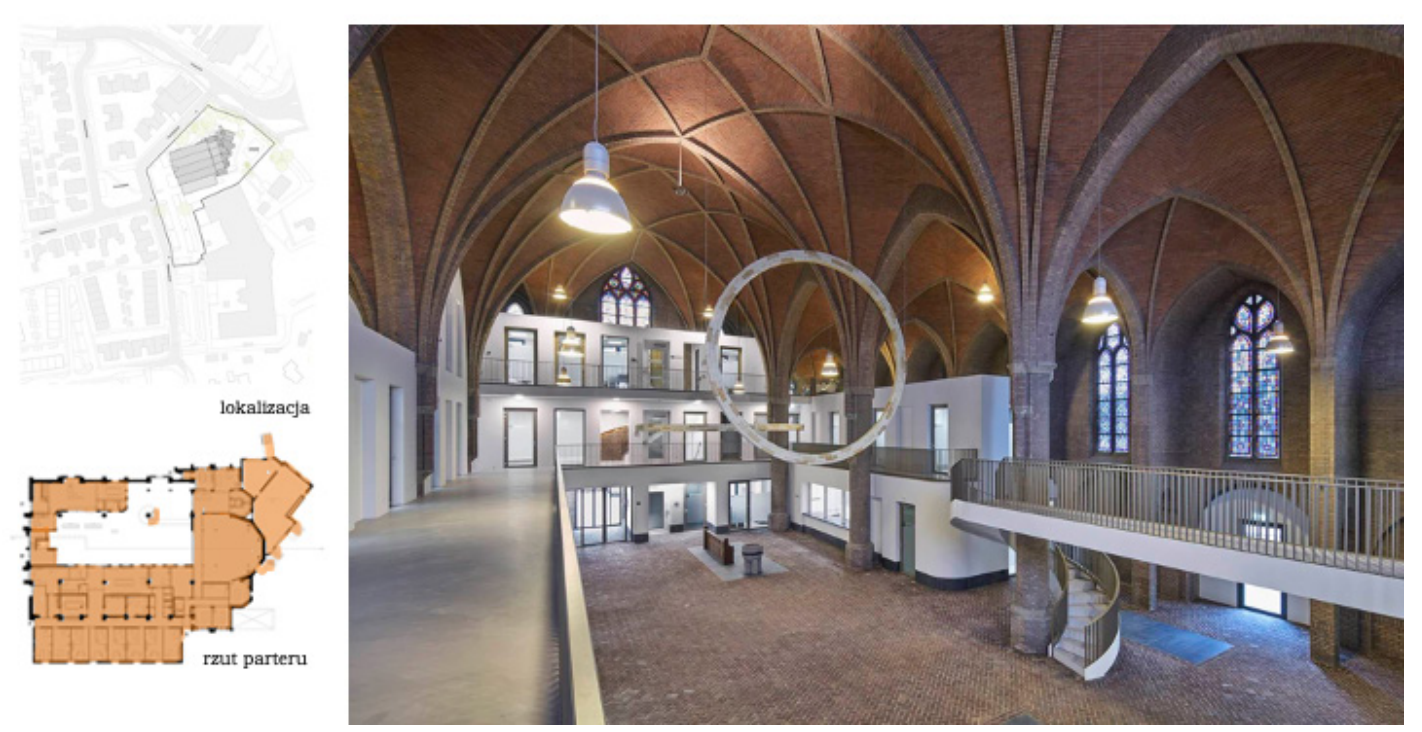

Il. 2. 'De poort van Borne’ Healthcare Center, Holandia (2017) - widok na wnętrze kościoła z nowym uzupełnieniem ahistorycznym, źródło: https://www.archdaily.com/891009/de-poort-van-borne-healthcare-centerreitsema-and-partners-architecten [dostęp: 20.09.2021).

\footnotetext{
7 Omawiane ściany na bazie styropianu EPS (zwane także lekkimi płytami kompozytowymi z pianobetonu) mogą być stosowane jako ściany nośne o konstrukcji jednokondygnacyjnej lub ściany działowe budynków wielokondygnacyjnych. Posiadają wytrzymałość na zginanie porównywalną z innymi materiałami murarskimi, a jednocześnie umożliwiają szybszą budowę przy zmniejszeniu całkowitej masy budynku. Omawiana konstrukcja jest przedmiotem badań oraz eksperymentów ukierunkowanych na optymalizację metody zbrojenia panelu ściennego. Szczegółowe badania na ten temat można odnaleźć m.in. w artykule: Mamat R., Rahim J., Hamzah S. H., Behaviour of unreinforced expanded polystyrene lightweight concrete (EPS-LWC) wall panel enhanced with steel fibre, Journal of Engineering Science and Technology Vol. 10, No.12, 2015, ss. 1600-1614.
} 
- budynek jako muzeum, Kilkenny (Irlandia), 2017

Kolejny przykład interwencji projektowej znajduje się w Irlandii, w niewielkim miasteczku Kilkenny, w którym zachował się kamienny kościół parafialny pochodzący z XIII wieku. Nowy budynek pełni funkcję muzeum, w którym odsłonięto i wyeksponowano najstarsze fragmenty ścian kościoła, a w posadzce umieszczono świetliki skierowane na odkryte podczas prac relikty archeologiczne. Warunek czytelności historycznej struktury i funkcji został w ten sposób spełniony. Obiekt jest otoczony przez niewielki cmentarz, który został otwarty i udostępniony dla mieszkańców. Od niedawna funkcjonuje jako lokalny ogród pamięci. W 2010 roku przy wsparciu samorządu lokalnego rozpoczęto prace konserwatorskie i projektowe ukierunkowane na przywrócenie pierwotnego układu funkcjonalno-przestrzennego kościoła. W tym celu zaprojektowano dwie kubatury. Są to współczesne uzupełnienia tzw. parahistoryczne w miejscu niezachowanego prezbiterium oraz nawy bocznej. Ocenie konserwatorskiej poddano uzupełnienie odtwarzające kubaturę nawy bocznej (Il. 3). Nowa forma przestrzenna jest dobrze odróżnialna od starej tkanki zabytku, przy jednoczesnym spełnieniu kryterium wzajemnej spójności i integralności kompozycyjnej oraz kolorystycznej. Projektowana kubatura obłożona blachą ołowianą stara się odtworzyć swoim kształtem dawny gabaryt nawy bocznej. W projekcie zastosowano ciekawy zabieg architektoniczny, a mianowicie zaakcentowanie dwuspadowego kształtu dachu w rysunku elewacji szczytowej poprzez lekkie wycofanie narożnej części bryły. Obiekt ten nie pretenduje do spełnienia kryterium odwracalności zmian, ponieważ powstał jako trwałe, docelowe uzupełnienie w ramach zabiegu tzw. reintegracji bryły kościoła.

Medieval Mile Museum, Kilkenny (Irlandia), 2017 r.
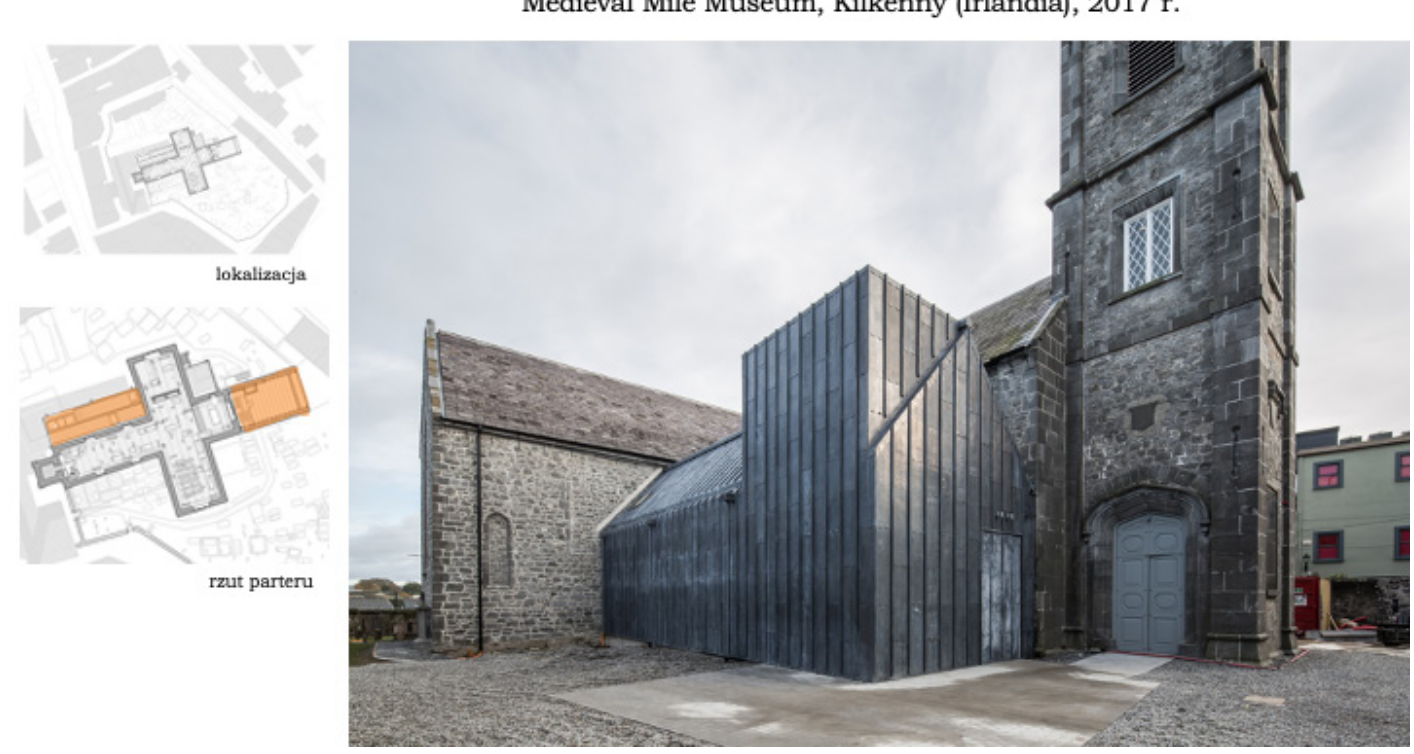

Il. 3. Medieval Mile Museum Kilkenny, Irlandia (2017) - zestawienie kubatury historycznej ze współczesnym uzupełnieniem, źródło: https://www.archdaily.com/875457/medieval-mile-museumkilkenny-ireland-mccullough-mulvin-architects (dostęp: 20.09.2021). 


\section{- sala wielofunkcyjna, Vilanova de la Barca (Hiszpania), 2016}

Ostatnim przykładem interwencji projektowej, który został objęty badaniami, jest realizacja ze słonecznej Hiszpanii, która w zasadzie spełnia wszystkie sformułowane wcześniej kryteria oceny (z wyjątkiem kryterium odwracalności zmian). Jest to projekt tzw. konsolidacji bryły zabytkowej ruiny (Il. 4). Kościół powstał w XIII wieku. Został częściowo zburzony w 1936 roku z powodu bombardowań podczas hiszpańskiej wojny domowej. Projekt zakłada przywrócenie pierwotnych gabarytów kościoła poprzez dodanie nowej, ceramicznej struktury częściowo wspartej na pozostałościach starożytnych murów. Kryterium jednoznacznej odróżnialności nowej formy od starej zostało spełnione.

Santa María de Vilanova de la Barca, Barcelona (Hiszpania), 2016 r.
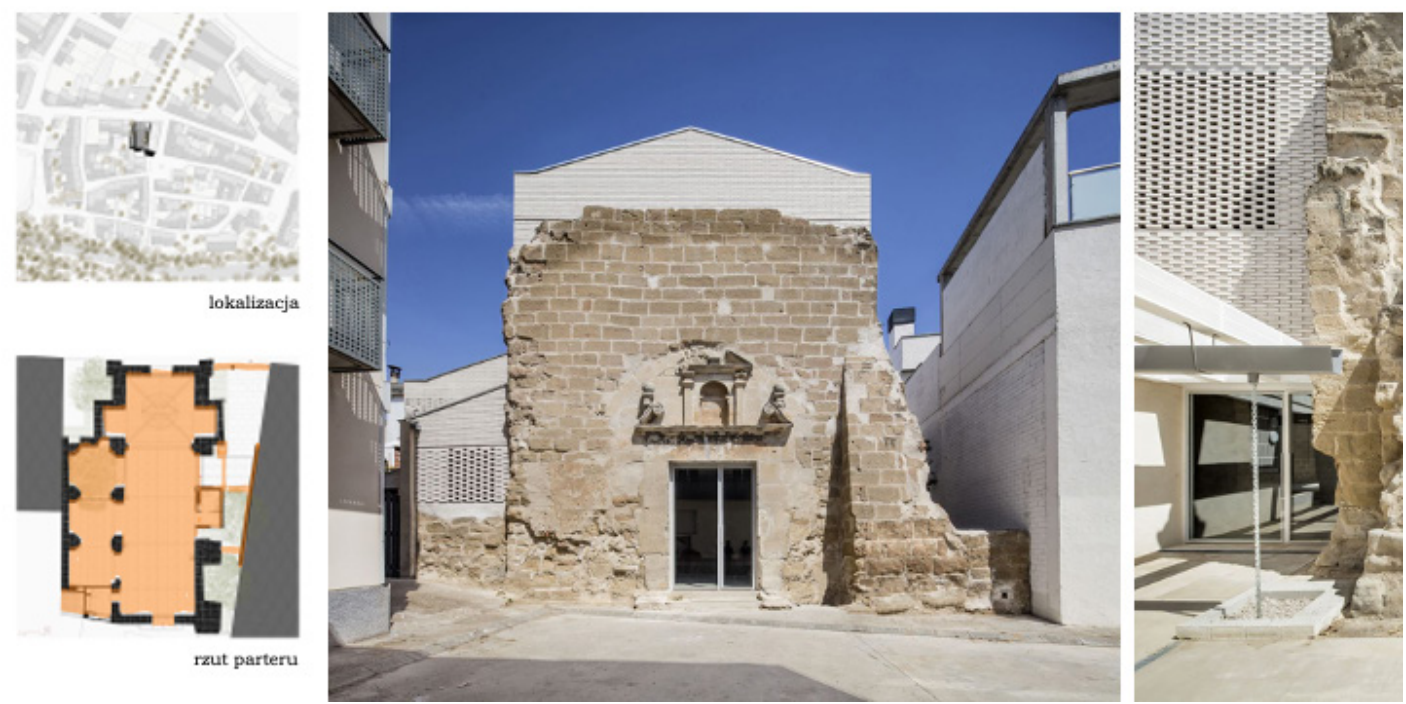

Il. 4. Santa Maria de Vilanova de la Barca, Hiszpania (2016) - zestawienie historycznej ruiny ze współczesną kubaturą, źródło: https://www.archdaily.com/803620/santa-maria-de-vilanova-de-la-barca-aleaoleaarchitecture-and-landscape (dostęp: 20.09.2021).

Obiekt został zaadaptowany na salę wielofunkcyjną. Zrezygnowano ze stałych elementów wyposażenia wnętrza na rzecz zachowania jego jednoprzestrzennego charakteru (Il. 5). Dzięki temu w całości pozostaje czytelna historyczna struktura i pierwotna funkcja zabytku. Zastosowane rozwiązania konstrukcyjno-materiałowe znakomicie współgrają z tkanką zabytkową, eksponują i podkreślają jej charakter oraz tektonikę. Nie starają się z nią konkurować. Stanowią rodzaj neutralnego tła dla nieregularnych narysów murów obwodowych kościoła. Użytkownik tak zaaranżowanej przestrzeni ma szansę poczuć upływ czasu; stać się świadkiem dialogu architektonicznego między starym a nowym - przeszłością i teraźniejszością. 


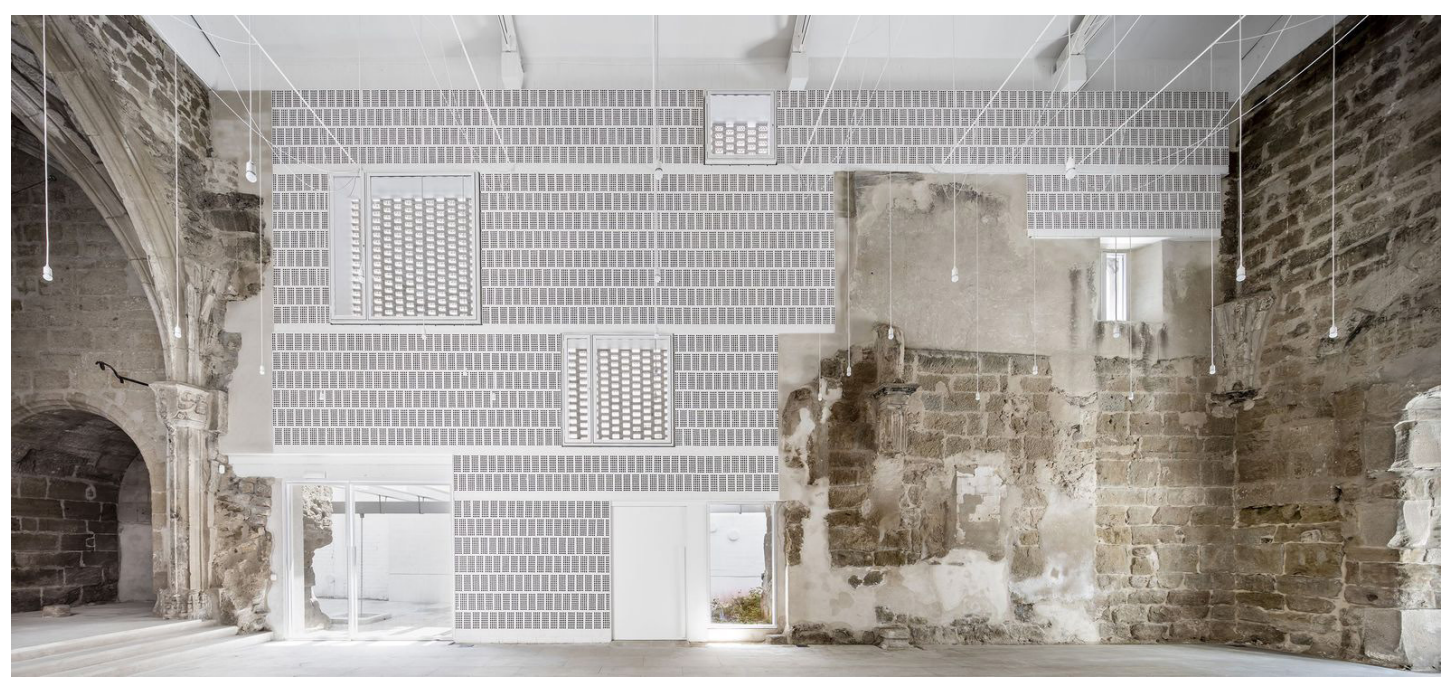

Il. 5. Santa Maria de Vilanova de la Barca, Hiszpania (2016) - widok na wnętrze zadaszonych ruin, źródło: https:// www.archdaily.com/803620/santa-maria-de-vilanova-de-la-barca-aleaolea-architecture-and-landscape (dostęp: 20.09.2021).

\section{Podsumowanie i wnioski}

W wyniku badań opracowano wnioski końcowe stanowiące próbę wyodrębnienia zestawu preferowanych cech współczesnych ingerencji projektowych i uzupełnień architektonicznych w zabytkowych obiektach sakralnych. Wnioski podzielono na funkcjonalne, przestrzenne oraz konstrukcyjno-materiałowe:

-funkcjonalne

- Dobór właściwego programu użytkowego w ramach adaptacji zabytku wynikający ze zrozumienia jego lokalizacji, zidentyfikowanych wartości, stanu technicznego i układu funkcjonalno-przestrzennego;

- Zastosowanie programu użytkowego pozwalającego na zachowanie czytelności historycznej funkcji sakralnej zabytku;

- Podział zabytku na strefy funkcjonalne powinien zależeć od rangi adaptowanej przestrzeni (prezbiterium, nawa główna, nawy boczne, chór, kruchta itd.);

- Adaptacja wnętrza sakralnego na salę wielofunkcyjną pozytywnie wpływa na zachowanie czytelności historycznego układu funkcjonalno-przestrzennego (np. zachowanie jednoprzestrzennego charakteru).

\section{- przestrzenne}

- Spełnienie kryterium jednoznacznej odróżnialności współczesnych form przestrzennych od historycznych;

- Stosowanie zabiegu reintegracji, konsolidacji bryły zabytku, mającego na celu uczytelnienie historycznej struktury, układu f-p (uzupełnienia parahistoryczne); 
- Zachowanie spójności kompozycyjnej współczesnych i historycznych form przestrzennych (wielkość i kształt kubatur, artykulacja elewacji, rozwiązania barwne);

- Sposób ukształtowania dodawanej formy przestrzennej powinien akcentować podłużne osie kościoła: poprzez symetrię osiową nowej formy lub jej miejscowe wycofanie (prezbiterium);

- konstrukcyjno-materiałowe

- Stosowanie możliwie jak najbardziej niezależnej, odwracalnej, samonośnej struktury (traktowanie nowej formy przestrzennej jako element wyposażenia wnętrz);

- Transparentność dodawanych form przestrzennych - ekspozycja wewnętrzna i zewnętrzna struktury historycznej (np. szkielet stalowy, drewniany);

- Lekkość i elastyczność w kształtowaniu form (np. przy użyciu systemu ścian ze wzmocnionego polistyrenu z natryskiem betonowym);

- Dobór współczesnych materiałów wykończeniowych w oparciu na kryterium spójności i integralności kompozycyjnej z historyczną strukturą (kolorystyka jako czynnik ich integracji - harmonijnie dobrana barwa, temperatura, faktura itd.);

- Stosowanie opaski wokół murów ceglanych i kamiennych np. z kruszywa lub ażurowych płyt jako zabezpieczenie dolnych partii budynku przed długotrwałym zawilgoceniem (korzystny wpływ na naturalny proces osuszania ścian). Należy unikać stosowania zbyt szczelnych opasek utrudniających parowanie wilgoci z gruntu, powodujących zawilgocenie oraz wysalanie murów ścian zabytkowych.

Przedstawione powyżej wnioski końcowe nie wyczerpują problematyki dopuszczalnych zmian $\mathrm{w}$ formę zabytkowych obiektów sakralnych. Przedstawione w pracy kryteria oceny przykładów interwencji projektowych w obiektach sakralnych w Europie mogą stać się punktem wyjścia do przeanalizowania szerszego zbioru współczesnych kreacji architektoniczno-konserwatorskich. Zakres, granice przekształceń, a także preferowany zestaw cech nowych uzupełnień architektonicznych w historycznej strukturze powinien zostać szczegółowo rozpoznany przez interdyscyplinarny zespółbadaczy. Należy rozważyć konieczność opracowania dokumentu, który we współczesnym dyskursie konserwatorskim mógłby służyć architektom i konserwatorom jako zbiór zasad ochrony zabytkowej architektury sakralnej.

${ }^{8}$ Przykładem takiego dokumentu może być np. Karta ochrony historycznych ruin przyjęta Uchwałą Walnego Zgromadzenia Członków PKN ICOMOS dnia 4 grudnia 2012 roku. Karta zawiera zbiór zasad ochrony historycznych ruin. Jej zapisy są wykorzystywane jako narzędzie do krytycznej oceny przekształceń historycznych ruin wybranych obiektów. 


\section{Bibliografia}

Białkiewicz A., O zmianach użytkowania obiektów sakralnych, Kraków: Wydawnictwo Politechniki Krakowskiej, 2016.

Długosz D., Adaptacja zabytkowych kościołów katolickich do nowych funkcji na wybranych przykładach $w$ Polsce oraz w Europie Zachodniej. Rozprawa doktorska, promotor: prof. zw. dr hab. inż. arch. Andrzej Kadłuczka, Politechnika Krakowska im. Tadeusza Kościuszki, 2019, https://repozytorium.biblos.pk.edu.pl/redo/resources/43226/file/resourceFiles/DlugoszD_ AdaptacjaZabytkowych.pdf (dostęp 28.11.2020).

Doroz-Turek M., Wartość sacrum w wybranych adaptacjach zdesakralizowanych kościołów i założeń klasztornych, [w:] Ochrona wartości w procesie adaptacji obiektów zabytkowych, Warszawa: PKN ICOMOS, 2015, ss. 85-103.

Dyczewski L., Wyganiane sacrum powraca, [w:] Miasto i sacrum, Kraków: Zakład Wydawniczy NOMOS, 2011, ss. 257-260.

Kurek J., Laicyzacja sacrum. Współczesna adaptacja świątyń do nowych funkcji, Przestrzeń i Forma, nr 15, 2011, ss. 225-234.

Mamat R., Rahim J., Hamzah S. H., Behaviour of unreinforced expanded polystyrene lightweight concrete (EPS-LWC) wall panel enhanced with steel fibre, Journal of Engineering Science and Technology Vol. 10, No.12, 2015, ss. 1600-1614, https://www.researchgate.net/ profile/Siti-Hawa-Hamzah/publication/286843523_Behaviour_of_unreinforced_expanded_ polystyrene_lightweight_concrete_EPS-LWC_wall_panel_enhanced_with_steel_fibre/ links/5dc136a4a6fdcc21280512ad/Behaviour-of-unreinforced-expanded-polystyrenelightweight-concrete-EPS-LWC-wall-panel-enhanced-with-steel-fibre.pdf.

Nieszczerzewska M., Ruiny architektury sakralnej. Śmierć miejsca - śmierć sacrum? Zeszyty Naukowe Centrum Badań im. Edyty Stein, nr 9, 2015, ss. 273-288.

Tomaszewski A., Ku nowej filozofii dziedzictwa, Kraków: Międzynarodowe Centrum Kultury, 2012, ss. 119-120.

Wojtuszek M., Niezależna struktura konstrukcyjna jako sposób adaptacji funkcjonalnej obiektów sakralnych, 2013, https://repolis.bg.polsl.pl/dlibra/publication/24106/edition/22340/content (dostęp: 28.11.2020).

Wojtuszek M., Architektoniczne aspekty adaptacji kościołów w Europie. Rozprawa doktorska, promotor: dr hab. inż. arch. Jan Pallado, Politechnika Śląska, 2015, https://delibra.bg.polsl.pl/ dlibra/show-content/publication/edition/33850?id=33850 (dostęp: 28.11.2020). 